Penerapan Model Mastery....(Yulianita)

\title{
PENERAPAN MODEL MASTERY LEARNING PADA PESERTA DIDIK SMP NEGERI 2 PALEMBANG DALAM MENINGKATKAN HASIL BELAJAR MATEMATIKA
}

\author{
Oleh: Yulianita \\ Email: yulianita@gmail.com \\ (SMP Negeri 2 Palembang)
}

\begin{abstract}
Abstrak
Permasalahan mendasar dalam penelitian ini adalah sebagian besar peserta didik kelas IX.I SMP Negeri 2 Palembang kurang memahami tentang Memahami kesebangunan bangun datar dan penggunaannya dalam pemecahan masalah. Tujuan yang diharapkan dari penelitian ini adalah untuk mengetahui peningkatan hasil belajar Matematika setelah diterapkan model pembelajaran Mastery Learning pada peserta didik kelas IX.I SMP Negeri 2 Palembang. Subjek dalam penelitian ini adalah peserta didik Kelas IX.I SMP Negeri 2 Palembang yang berjumlah 32 peserta didik. Penelitian ini akan dilaksanakan pada semester ganjil di kelas IX.I pada bulan Agustus s/d Oktober tahun 2019. Penelitian tindakan kelas ini telah dikatakan tuntas dengan dibuktikannya peningkatan hasil belajar Matematika menggunakan model pembelajaran Mastery Learning. Ketuntasan belajar meningkat dari Pra siklus, siklus I ke siklus II yaitu masing-masing 56,25\%, 78,13\% dan 87,50 \% Pada siklus II ketuntasan belajar peserta didik secara klasikal telah tercapai dan mengalami peningkatan yang sangat baik.
\end{abstract}

Kata Kunci: Mastery Learning, Hasil Belajar Matematika

\section{IMPLEMENTATION OF MASTERY LEARNING MODELS OF STUDENTS SMP NEGERI 2 PALEMBANG IN IMPROVING MATHEMATICS LEARNING RESULTS}

\begin{abstract}
The fundamental problem in this research is that most students of class IX.I SMP Negeri 2 Palembang do not understand about understanding the similarity of flat shapes and their use in problem solving. Starting from the description above, the problem in this study is formulated, namely the problem formulation in this study are: "How is the increase in mathematics learning outcomes after the application of the Mastery Learning learning model in class IX.I students of SMP Negeri 2 Palembang?". The expected objective of this study was to determine the increase in mathematics learning outcomes after the Mastery Learning learning model was applied to class IX.I students of SMP Negeri 2 Palembang. The subjects in this study were 32 students of Class IX.I SMP Negeri 2 Palembang. This research will be carried out in odd semesters in class IX.I from August to October 2019. This classroom action research has been said to be complete, proven by the improvement in mathematics learning outcomes using the Mastery Learning learning model. Completeness of learning
\end{abstract}


Wahana Didaktika Vol. 19 No.1 Januari 2021 : 17-30

increased from pre-cycle, cycle I to cycle II, namely $56.25 \%, 78.13 \%$ and $87.50 \%$ respectively. In the second cycle, classical student learning completeness has been achieved and has increased very well.

Keywords: Mastery Learning, Mathematics Learning Result

\section{A. PENDAHULUAN}

Mahmud dan Hartono (2014, p.192) mengatakan bahwa matematika dapat dipahami siswa sangat tergantung pada interaksi maupun kerja sama antara guru dan siswa. Guru harus dapat memberikan pembelajaran yang efektif dan menyenangkan bagi siswa serta melibatkan siswa secara aktif dalam mengkonstruksi pengetahuan. Siswa juga harus mampu melibatkan dirinya dengan usaha dan pengetahuannya dalam mempelajari matematika. Jika salah satunya pasif atau tidak ada interaksi yang baik maka akan timbul permasalahanpermasalahan dalam matematika seperti: pembelajaran matematika terasa monoton atau tidak menyenangkan bagi siswa, hasil belajar matematika rendah, kesulitan siswa dalam mempelajari matematika, kemampuan berpikir siswa rendah baik penalaran, kritis maupun kreatif, pemahaman siswa sedikit, sikap siswa terhadap matematika negatif dan sebagainya.

Berdasarkan temuan hasil ulangan harian di kelas IX.1 SMP Negeri 2 Palembang di temukan hasil ulangan yang masih rendah . Target KKM yang haru di capai oleh peserta didik adalah nilai 75 dapat di katakana tuntas Hasil ulangan Matematika belum bisa di katakan berhasil karena dalam 32 peserta didik yang mengikuti ulangan harian Matematika terdapat 14 peserta didik yang belum mencapai ketuntasan yang di harapkan KKM 75 dan hanya 18 peserta didik yang mampu melewati nilai KKM.

Beranjak dari rendah nya nilai hasil ulangan harian matematika kelas IX.1 SMP Negeri 2 Palembang disebakan antara lain sebagai berikut; Peserta didik masih banyak yang mengobrol dengan teman sebangku. Peserta didik tidak bertanya apabila ada kesulitan dalam belajar. Guru kurang memperhatikan peserta didik yang belum mengerti.Guru masih kurang menggunakan model pembelajaran yang tepat dalam proses belajar mengajar yang masih konvensional yang berfokus kepada guru 
Maka dari itu perlunya sebuah sikap dari guru untuk meningkatkan hasil belajar matematikan kelas IX.I SMP Negeri 2 Palembang sehingga permasalahan tidak berlarut terlalu lama. Peserta didik bisa lebih aktif dan semangat dalam mengikutiti pembelajaran matematika. Salah satu model pembelajaran yang dapat meningkatkan hasil belajar matematika peserta didik adalah model Mastery Learning (pembelajaran tuntas). Model Pembelajaran adalah suatu pedoman bagi guru dalam melaksanakan kegiatan belajar mengajar yang dilakukan di dalam kelas. Di dalam hal ini guru bebas untuk memilih model pembelajaran yang sesuai agar mencapai tujuan pembelajaran.

Menurut Rusman (2014, p.47), model pembelajaran adalah suatu rencana atau pola yang dapat digunakan untuk membentuk kurikulum (rencana pembelajaran jangka panjang), merancang bahan-bahan pembelajaran dan membimbing pembelajaran di kelas atau yang lain. Model Mastery Learning adalah pencapaian taraf penguasaan minimal yang ditetapkan untuk setiap unit bahan pelajaran baik secara perseorangan maupun kelompok, dengan kata lain apa yang dipelajari siswa dapat dikuasai sepenuhnya (Usman, 1993, p.96).

Berdasarkan latar belakang di atas, adapun rumusan masalah dalam penelitian ini adalah apakah Penerapan Model Pembelajaran Mastery Learning Pada Peserta Didik Kelas IX.1 SMP Negeri 2 Palembang dapat meningkatan Hasil Belajar Matematika. Sesuai dengan rumusan masalah di atas, maka penelitian ini bertujuan untuk mengetahui peningkatan hasil belajar Matematika setelah diterapkan model pembelajaran Mastery Learning pada peserta didik kelas IX.1 SMP Negeri 2 Palembang.

Proses belajar merupakan sebuah aktivitas yang penting dalam menentukan keberhasilan pendidikan. Sudjana (2009, p.3) mendefinisikan hasil belajar siswa pada hakikatnya. Selain itu, Suyono dan Hariyanto (2011, p.18) juga menegaskan bahwa pembelajaran yang paling efektif bagi peserta didik ternyata diperoleh melalui metode belajar sambil mengajar (Learning by Teaching). Teaching diarahkan untuk proses pembelajaran guru saat berada dikelas, berhadapan dengan peserta didik, merencanakan dan mengevaluasinya. sedangkan learning merupakan konsep untuk pembelajar agar dapat menyerap fakta, konsep, 
prosedur, dan prinsip sebuah ilmu dengan cara cepat, menyenangkan, dan berkesan.

Selanjutnya Sanjaya (2010, p.87) mengemukakan bahwa hasil belajar tingkah laku sebagai hasil belajar dirumuskan dalam bentuk kemampuan dan kompetensi yang dapat diukur atau dapat ditampilkan melalui performance siswa. Istilah-istilah tingkah laku dapat diukur sehingga menggambarkan indicator hasil belajar adalah mengidentifikasi (identify), menyebutkan (name), menyusun (construct), menjelaskan (describe), mengatur (order), dan membedakan (different). Sedangkan istilah-istilah untuk tingkah laku yang tidak menggambarkan indikator hasil belajar adalah mengetahui, menerima, memahami, mencintai, mengira-ngira, dan lain sebagainya.

Selanjutnya, menurut Slameto (2010, p.3) menyatakan hasil belajar sebagai perubahan yang terjadi dalam diri seseorang berlangsung secara berkesinambungan, tidak statis. Satu perubahan yang terjadi akan menyebabkan perubahan berikutnya dan akan berguna bagi kehidupan ataupun proses belajar berikutnya. Hasil belajar yang dicapai peserta didik dipengaruhi dua faktor utama yakni faktor lingkungan dan faktor yang datang dari diripeserta didikitu sendiri terutama kemampuan yang dimilikinya. Dari beberapa pendapat dapat disimpulkan bahwa hasil belajar merupakan hasil akhir yang diperoleh peserta didik setelah proses belajar mengajar terjadi.

Matematika merupakan ilmu universal yang mendasari perkembangan teknologi modern, mempunyai peran penting dalam berbagai disiplin dan memajukan daya pikir manusia. Suwangsih (2006, p.3) menyatakan bahwa kata matematika berasal dari perkataan Latin "Mathematika" yang mulanya diambil dari prakata Yunani "Mathematike" yang berarti mempelajari. Adji \& Maulana (2006, p.34) mengemukakan bahwa matematika adalah bahasa, sebab matematika merupakan bahasa simbol yang berlaku secara universal (internasional) dan sangat padat makna dan pengertiannya.

Mastery learning merupakan suatu pendekatan pembelajaran yang menganut azas ketuntasan belajar. Belajar tuntas (Mastery Learning) adalah pendekatan pembelajaran berdasar pandangan filosofis bahwa seluruh peserta 
didik dapat belajar jika mereka mendapat dukungan kondisi yang tepat. Konsep belajar tuntas adalah proses belajar yang bertujuan agar bahan ajaran dikuasai secara tuntas, artinya cara menguasai materi secara penuh. Belajar tuntas ini merupakan strategi pembelajaran yang di individualisasikan dengan menggunakan pendekatan kelompok. Dengan sistem belajar tuntas diharapkan proses belajar mengajar dapat dilaksanakan agar tujuan instruksional yang akan dicapai dapat diperoleh secara optimal sehingga proses belajar lebih efektif dan efisien. (Sukmadinata \& Syaodih, 2005, p.24)

Model belajar tuntas ini terdiri atas lima tahap, yaitu orientasi (orientation), penyajian (presentation), latihan terstruktur (structured practice), latihan terbimbing (guided practice) dan latihan mandiri (independent practice). Tujuan proses belajar mengajar secara ideal adalah agar bahan yang dipelajari dikuasai sepenuhnya oleh peserta didik. Ini disebut mastery learning atau belajar tuntas, artinya penguasaan penuh (Nasution, 2011, p.36)

\section{B. METODOLOGI PENELITIAN}

Penelitian ini termasuk jenis penelitian tindakan kelas (PTK), dengan ciri utamanya adalah adanya tindakan yang berulang dan metode utamanya adalah refleksi diri yang bertujuan untuk memperbaiki pembelajaran. PTK merupakan kegiatan pemecahan masalah yang bercirikan siklik dan reflektif yang dimulai dari: a) perencanaan (planning), b) pelaksanaan tindakan (action), c) mengumpulkan data (observing), d) menganalisis data/ informasi untuk memutuskan sejauh mana kelebihan dan kekurangan tindakan tersebut (reflecting). PTK bercirikan perbaikan terus menerus sehingga kepuasaan penelitian sering menjadi tolak ukur siklus tersebut.

Arikunto (2006) menyatakan bahwa penelitian tindakan kelas dapat dilaksanakan melalui empat langkah utama yaitu perencanaan, tindakan, observasi, dan refleksi. Empat langkah utama yang saling berkaitan itu dalam pelaksanaan penelitian tindakan kelas sering disebut dengan istilah 1 (satu) siklus. Keempat langkah tersebut membentuk sebuah siklus yang beruntun dan 
selanjutnya kembali ke langkah semula. Namun penelitian tindakan kelas minimal dilakukan dalam 2 (dua) siklus untuk dapat mengambil kesimpulan.

Penelitian akan dilaksanakan pada siswa kelas IX.1 SMP Negeri 2 Palembang tahun ajaran 2019/2020. Alasan peneliti memilih lokasi di kelas IX.1 SMP Negeri 2 Palembang ini dikarenakan adanya relasi sehingga dapat bekerja sama dengan kepala sekolah dan guru kelas yang bersangkutan, sehingga peneliti tertarik untuk melakukan penelitian. Penentuan tempat ini diharapkan memberi kemudahan khususnya menyangkut kebiasaan yang dilakukan dalam lingkungannya yang berhubungan dengan siawa sebagai objek

Subjek dalam penelitian ini adalah siswa kelas IX.1 SMP Negeri 2 Palembang tahun ajaran 2019/2020 dengan jumlah peserta didik 32 siswa. Subjek penelitian ini sangat heterogen dilihat dari kemampuannya, yakni ada sebagian peserta didik yang mempunyai kemampuan tinggi, sedang, dan rendah. Alasan peneliti menggunkan peserta didik kelas IX.1 SMP Negeri 2 Palembang sebagai subjek penelitian, karena berdasarkan hasil observasi pada saat pembelajaran guru hanya menggunakan metode ceramah dan peserta didik tidak dilibatkan dalam aktivitas belajar. Selain itu, adanya permasalahan yang dihadapi oleh guru di sekolah tersebut yaitu mengenai hasil belajar peserta didik yang masih rendah, sehingga peneliti tertarik untuk melakukan penelitian dan beranggapan bahwa kelas IX.1 dalam pembelajaran ini guru harus pandai menggunakan model yang tepat agar hasil belajar peserta didik dapat tercapai dengan optimal.

Adapun indikator yang diharapkan dalam kegiatan penelitian ini adalah: Terjadi peningkatan hasil belajar yaitu di atas KKM 75 peserta didik tuntas belajar Matematika dan sebanyak $85 \%$ peserta didik mencapai ketuntasan belajar secara klasikal. Terjadi peningkatan pelaksanaan proses belajar mengajar yang diselenggarakan oleh guru. Penelitian ini diharapkan dapat meningkatkan hasil belajar matematika siswa dan perolehannya akan menfaat yang baik. Langkahlangkah yang ditempuh dalam penelitian ini yaitu: Perencanaan tindakan, Pelaksanaan tindakan, observasi dan analisis dan refleksi 
Penerapan Model Mastery....(Yulianita)

\section{HASIL PENELITIAN DAN PEMBAHASAN}

\section{Siklus I}

Kegiatan pendahuluan ini diawali dengan guru mengucap salam, mengkondisikan kelas menyiapkan alat pembelajaran. Setelah semuanya siap guru mengisi daftar hadir siswa. Selanjutnya guru menyampaikan tujuan pembelajaran dan prosedur pembelajaran. Siswa akan mengerjakan tugas yang diberikan oleh guru di lembar kerja secara berkelompok.

Guru menjelaskan tujuan pembelajaran, tugas-tugas yang akan dikerjakan dan mengembangkan tanggung jawab siswa. Langkah-langkah penting yang harus dilakukan pada tahap ini yaitu (1) guru menjelaskan tujuan pembelajaran dan syarat-syarat kelulusan, (2) menjelaskan materi pembelajaran serta kaitannya dengan pembelajaran terdahulu serta pengalaman sehari-hari siswa, dan (3) guru mendiskusikan langkah-langkah pembelajaran seperti berbagai komponenkomponen isi pembelajaran dan tanggung jawab siswa yang diharapkan selama proses pembelajaran.

Guru menjelaskan konsep-konsep atau keterampilan baru disertai dengan contoh-contoh. Penggunaan media pembelajaran, baik visual maupun audio visual sangat disarankan dalam penyajian materi pembelajaran. Dalam tahap ini perlu dilakukan evaluasi seberapa jauh siswa telah paham dengan materi yang diajarkan. Dengan demikian, siswa tidak akan mengalami kesulitan pada tahap latihan berikutnya. Guru memberikan siswa contoh praktik penyelesaian masalah, berupa langkah-langkah penting secara bertahap.

Dalam tahap ini siswa perlu diberi beberapa pertanyaan, kemudian guru memberikan balikan atas jawaban siswa. Guru memberikan kesempatan pada siswa untuk latihan menyelesaikan suatu permasalahan, tetapi masih dibawah bimbingan. Melalui kegiatan terbimbing ini memungkinkan guru untuk menilai kemampuan siswa dalam menyelesaikan tugas-tugas yang diberikan dan melihat kesalahan-kesalahannya. Guru memberikan latihan mandiri dilakukan apabila siswa telah mencapai skor untuk kerja antara 85\%-90\% dalam tahap latihan terbimbing. Peran guru dalam tahap ini adalah menilai hasil kerja siswa setelah selesai. 
Kegiatan terakhir adalah penutup, dalam tahap ini guru memberikan kesempatan kepada siswa untuk menyimpulkan hasil pembelajaran yang telah didapatkan, selanjutnya guru memberi penguatan terhadap simpulan yang disampaikan oleh siswa. Langkah terakhir adalah siswa dan guru melakukan refleksi. Selanjutnya guru menutup pelajaran dengan mengucapkan salam. Berdasarkan hasil belajar pada siklus 1 dapat di lihat pada table di bawah ini.

Tabel 1 Hasil belajar Siklus I

\begin{tabular}{|ll|}
\hline Jumlah Nilai & $=\mathbf{2 5 1 8}$ \\
\hline Jumlah Nilai Maksimal ideal & $=\mathbf{3 2 0 0}$ \\
\hline Rata-rata Nilai Tercapai & $=\mathbf{7 8 . 6 9}$ \\
\hline $\begin{array}{l}\text { Jumlah siswa yang belum } \\
\text { tuntas }\end{array}$ & $=\mathbf{7}$ \\
\hline Jumlah siswa yang tuntas & $=\mathbf{2 5}$ \\
\hline $\begin{array}{l}\text { Persentase Belum } \\
\text { tuntas }\end{array}$ & $=\mathbf{2 1 . 8 8}$ \\
\hline Persentase ketuntasan & $=\mathbf{7 8 . 1 3}$ \\
\hline Klasikal & $=$ Belum Tuntas \\
\hline
\end{tabular}

Bedasarkan tabel di atas dapat dijelaskan bahwa hasil belajar siklus I di kelas IX.I SMP Negeri 2 Palembang terdapat nilai rata- rata 78.69. Siswa yang mendapatkan nilai ketuntasan sebanyak 25 peserta didik dengan jumlah persentase $78 \%$. Sedangkan peserta didik yang belum tuntas yakni 7 peserta didik dengan persentase $21.88 \%$. Maka sesuai target ketuntasan yang telah di tetapkan peneliti,pada siklus I belum mencapai ketuntasan secara keseluruhan,karena terdapat 25 dari 32 peserta didik dengan persentase 78\%. Belum mencapai KKM yang telah di tetapkan yakni sebesar $85 \%$ ketuntasan secara keseluruhan. Jadi perlu nya perbaikan pada siklus berikutnya.

Proses keberhasilan pembelajaran memahami kesebangunan bangun datar dan penggunaannya dalam pemecahan masalah dengan menerapkan pembelajaran Model Pembelajaran Mastery Learning yang dilakukan oleh guru dapat dilihat dari lembar observasi. Berdasarkan pembelajaran yang dilaksanakan pada siklus I oleh pengamat, terlihat bahwa beberapa aspek yang telah dicapai dengan baik antara lain Guru melakukan proses pembelajaran sesuai dengan rencana pelaksanaan pembelajaran dengan baik. Guru menerapkan pembelajaran 
berbasis masalah pada menulis argumentasi dengan baik. Siswa dengan bimbingan guru menulis kembali hasil dari penyuntingan dengan baik.

\section{Siklus II}

Kegiatan pendahuluan ini diawali dengan guru mengucap salam, mengkondisikan kelas menyiapkan alat pembelajaran. Setelah semuanya siap guru mengisi daftar hadir siswa. Kemudian, guru melakukan apersepsi sebagai upaya untuk membangkitkan motivasi siswa dalam kegiatan pembelajaran.

Guru menjelaskan tujuan pembelajaran dan syarat-syarat kelulusan, (2) menjelaskan materi pembelajaran serta kaitannya dengan pembelajaran terdahulu serta pengalaman sehari-hari siswa, dan (3) guru mendiskusikan langkah-langkah pembelajaran seperti berbagai komponen-komponen isi pembelajaran dan tanggung jawab siswa yang diharapkan selama proses pembelajaran. Guru menjelaskan konsep-konsep atau keterampilan baru disertai dengan contohcontoh. Guru memberikan siswa contoh praktik penyelesaian masalah, berupa langkah-langkah penting secara bertahap. Guru memberikan kesempatan pada siswa untuk latihan menyelesaikan suatu permasalahan, tetapi masih dibawah bimbingan.

Melalui kegiatan terbimbing ini memungkinkan guru untuk menilai kemampuan siswa dalam menyelesaikan tugas-tugas yang diberikan dan melihat kesalahan-kesalahannya. Guru memberikan latihan mandiri dilakukan apabila siswa telah mencapai skor unjuk kerja dalam tahap latihan terbimbing. Peran guru dalam tahap ini adalah menilai hasil kerja siswa setelah selesai.

Sebelum guru menutup pembelajaran, siswa kembali pada tempat duduknya masing-masing. Setelah semua siswa duduk guru menanyakan tentang pembelajaran. Guru memberikan kesempatan kepada siswa untuk menyimpulkan hasil pembelajaran yang telah didapatkan, selanjutnya guru memberi penguatan terhadap simpulan yang disampaikan oleh siswa.Langkah terakhir adalah siswa dan guru melakukan refleksi. Selanjutnya guru menutup pelajaran dengan mengucapkan salam. 
Pengamatan pada siklus II sama dengan siklus I. Selama kegiatan berlangsung, observer melakukan observasi untuk melihat tindakan- tindakan guru dan aktivitas siswa saat proses pembelajaran memahami kesebangunan bangun datar dan penggunaannya dalam pemecahan masalah melalui model pembelajaran Mastery Learning. Berdasarkan hasil observasi didapatkan bahwa proses belajar mengajar yang berlangsung sudah jauh lebih baik daripada pelaksanaan kegiatan pada siklus I. Siswa terlihat lebih nyaman dan lebih antusias.

Tabel 2 Hasil Belajar Siklus II

\begin{tabular}{|ll|}
\hline Jumlah Nilai & $=\mathbf{2 7 2 2}$ \\
\hline Jumlah Nilai Maksimal ideal & $=\mathbf{3 2 0 0}$ \\
\hline Rata-rata Nilai Tercapai & $=\mathbf{8 5 . 0 6}$ \\
\hline $\begin{array}{l}\text { Jumlah siswa yang belum } \\
\text { tuntas }\end{array}$ & $=\mathbf{4}$ \\
\hline Jumlah siswa yang tuntas & $=\mathbf{2 8}$ \\
\hline $\begin{array}{l}\text { Persentase Belum } \\
\text { tuntas }\end{array}$ & $=\mathbf{1 2 . 5 0}$ \\
\hline Persentase ketuntasan & $=\mathbf{8 7 . 5 0}$ \\
\hline Klasikal & $=$ Tuntas \\
\hline
\end{tabular}

Berdasarkan tabel di atas dapat dijelaskan bahwa hasil belajar siklus II di kelas IX.I SMP Negeri 2 Palembang terdapat nilai rata- rata 85.06. Siswa yang mendapatkan nilai ketuntasan sebanyak 28 peserta didik dengan jumlah persentase $87.50 \%$. Sedangkan peserta didik yang belum tuntas yakni 4 peserta didik dengan persentase $12.50 \%$. Maka sesuai target ketuntasan yang telah di tetapkan peneliti,pada siklus II telah mencapai ketuntasan secara keseluruhan,karena terdapat 28 dari 32 peserta didik dengan persentase $87.50 \%$. Jadi tidak perlu di lanjutkan ke siklus berikutnya.

Berdasarkan hasil analisis observasi aktivitas guru pada siklus II, ada beberapa aspek yang sebelumnya pada siklus I masih kategori cukup baik, dan pada siklus II sudah menjadi kategori Amat baik , yaitu sebagai berikut: Guru telah memberikan apersepsi kepada siswa. Guru menjelaskan prosedur pembelajaran dengan baik Guru memberikan penjelasan mengenai materi dengan model pembelajaran Mastery Learning dengan baik. Guru membimbing 
siswa saat diskusi kelompok, guru mengarahkan membimbing siswa agar tetap fokus pada permasalahan yang dibahas. Guru telah menguasai kelas dengan baik pada saat siswa ribut guru memberikan teguran kepada siswa. Pada saat kegiatan penyuntingan hasil pekerjaan siswa, guru membimbing siswa dengan memberikan penguatan menyampaikan kesan terhadap pembelajaran.

\section{PEMBAHASAN}

Hasil penilaian dari observasi pada siklus II hasil penilaian dan observasi pada siklus II pada pembelajaran Matematika pada siswa kelas IX.I SMP Negeri 2 Palembang sudah mengalami peningkatan yang sangat baik. Sikap siswa dalam mengikuti kegiatan pembelajaran Memahami kesebangunan bangun datar dan penggunaannya dalam pemecahan masalah dengan menggunakan Model Pembelajaran Mastery Learning mengalami perubahan ke arah yang positif.

Hal ini dikarenakan guru berhasil membangkitkan gairah belajar siswa, sehingga siswa termotivasi untuk belajar. Selain itu, pada siklus II guru memberikan topik mengenai penyalahgunaan jejaring sosial lebih membuat siswa dengan jelas mengutarakan argumen dengan alasan yang beragam. Hal ini menunjukkan bahwa pembelajaran melalui model pembelajaran Mastery Learning merupakan cara yang sangat baik untuk meningkatkan keterampilan siswa berargumentasi.

Peningkatan hasil tes belajar dapat dilihat pada tabel berikut ini:

Tabel 3 Pembahasan Hasil Belajar

\begin{tabular}{|c|c|c|c|}
\hline $\begin{array}{c}\text { Proses } \\
\text { Pembelajaran }\end{array}$ & $\begin{array}{c}\text { Persentase } \\
\text { Ketuntasan }\end{array}$ & $\begin{array}{c}\text { Jumlah } \\
\text { Ketuntasan }\end{array}$ & $\begin{array}{c}\text { Nilai Rata } \\
\text { Rata }\end{array}$ \\
\hline Pra Siklus & 56.25 & 18 & 73.66 \\
\hline Siklus I & 78.13 & 25 & 78.69 \\
\hline Siklus II & 87.50 & 28 & 85.06 \\
\hline
\end{tabular}

Dari tabel tersebut dapat dilihat bahwa rata-rata nilai tes siswa pada pra siklus 73,66. Nilai rata-rata hasil belajar siklus 1 adalah 78.69. Pada siklus 1 siswa yang memperoleh nilai tertinggi dari 95 siswa, sedangkan nilai terendah 
dengan nilai 65. Pada siklus II rata-rata nilai tes siswa adalah 85,06. Pada siklus II siswa yang memperoleh nilai tertinggi dari 32 siswa yang mengikuti tes adalah nilai 100, sedangkan nilai terendah dengan nilai 60 . Hasil tes ini sudah cukup memuaskan, karena terjadi peningkatan siklus II $(87,50)$. Jumlah persentase daya serap pada siklus 1 adalah $78,13 \%$.

Pada siklus II persentase daya serap siswa mengalami peningkatan sebesar menjadi 87,50 \%. Artinya, siswa sudah memahami secara baik materi pelajaran yang diajarkan dan siswa dapat belajar argumentasi dengan baik. Data tersebut menunjukkan bahwa terjadinya peningkatan pada setiap siklus. Ketuntasan belajar diperoleh memenuhi kriteria bahkan dapat dikategorikan memuaskan, sebab kriteria ketuntasan minimum (KKM) secara klasikal SMP Negeri 2 Palembang adalah 75 dan yang dicapai pada siklus II tersebut melebihi standar minimum $85 \%$. Walaupun pada siklus 1 ketuntasan belajar siswa secara klasikal belum memuaskan, tetapi pada siklus II ketuntasan belajar secara klasikal sudah cukup memuaskan, karena sudah mencapai target yang telah ditetapkan yaitu $85 \%$ siswa mendapatkan nilai 75 ke atas.

Peningkatan hasil belajar pra siklus, siklus 1 dan siklus II dapat dilihat pada grafik di bawah ini:

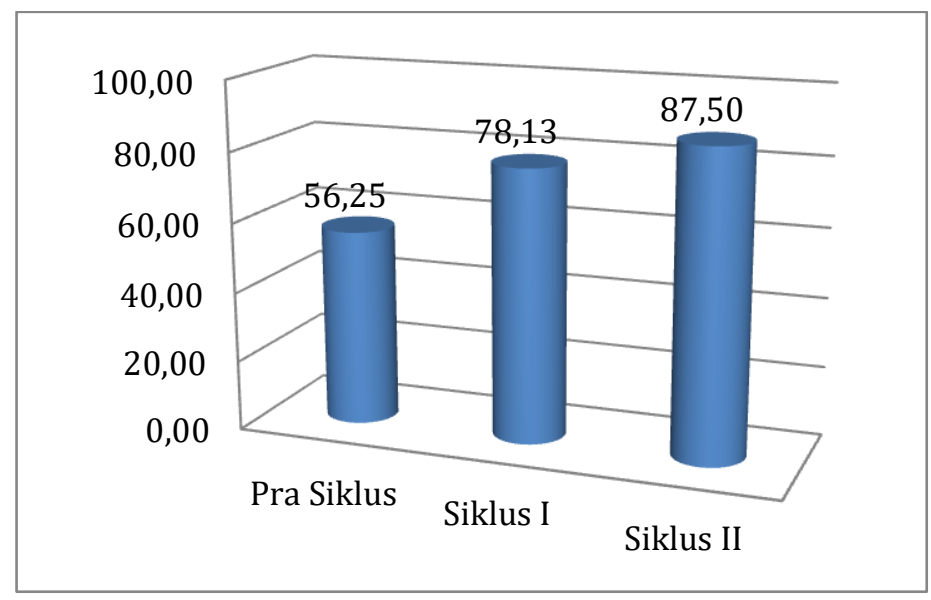

Grafik 1. Hasil Belajar Matematika

Peningkatan-peningkatan yang cukup baik tersebut disebabkan kelemahan-kelemahan pada siklus I berhasil diperbaiki pada siklus II. Pada peningkatan aktivitas siswa tentu saja dipengaruhi oleh faktor kemampuan 
guru dalam menjelaskan dan membimbing proses belajar Matematika melalui model pembelajaran Mastery Learning.

\section{SIMPULAN}

Berdasarkan hasil penelitian dari siklus I dan II, dapat disimpulkan bahwa pembelajaran Matematika melalui Model Pembelajaran Mastery Learning dapat meningkatkan hasil belajar siswa kelas IX.I SMP Negeri 2 Palembang tahun ajaran 2019-2020. Melalui model pembelajaran Mastery Learning pada pembelajaran Matematika yang pertama siswa masih terlihat tidak aktif dalam mengikuti pembelajaran. Namun, pada siklus kedua aktivitas belajar siswa terlihat menjadi lebih aktif hal ini dikarenakan guru menjelaskan model pembelajaran Mastery Learning pada pembelajaran Matematika dengan pelan-pelan sehingga siswa menjadi paham dengan tugas yang diberikan.

Melalui Model Pembelajaran Mastery Learning yang kedua siswa dapat dengan mudah menuangkan gagasan serta ide berdasarkan dengan topik permasalahan yang diberikan. Model Pembelajaran Mastery Learning ini merupakan pembelajaran yang penyampaiannya dilakukan dengan menyajikan suatu permasalahan, dari permasalahan yang diberikan siswa berkonstribusi dalam diskusi kelompok untuk menyelesaikan masalah yang diberikan dengan mengumpulkan informasi, eksperimen untuk mendapatkan penjelasan dan pemecahan masalah, serta pengumpulan data, terhadap permasalahan yang diberikan. 


\section{DAFTAR PUSTAKA}

Adjie, Nahrowi \& Maulana. (2006). Pemecahan Masalah Matematika. UPI PRESS. Bandung.

Arikunto, Suharsimi. (2006). Prosedur Penelitian Suatu Pendekatan Praktik. Jakarta: PT. Rineka Cipta.

Mahmud, Djuwita Amin dan Hartono. (2014). Keefektifan Model Pembelajaran Isk dan di Ditinjau dari Motivasi, Sikap, dan Kemampuan Komunikasi Matematis. Universitas Muhammadiyah Maluku Utara, Universitas Negeri Yogyakarta. (tidak diterbitkan).

Nasution. (2011). Berbagai Pendekatan dalam Proses Belajar Mengajar. Jakarta: PT Bumi Aksara.

Rusman. (2014). Model-Model Pembelajaran (Mengembangkan Profesionalisme Guru). Jakarta: Raja Grafindo Persada.

Sanjaya, Wina. (2010). Strategi Pembelajaran Berorientasi Standar Proses Pendidikan. Jakarta: Kencana.

Slameto. (2010). Belajar dan Faktor-Faktor Yang Mempengaruhi. Jakarta: PT. Rineka Cipta.

Sudjana, N. (2009). Dasar-dasar Proses Belajar Mengajar. Bandung: Sinar Baru Algensindo.

Sukmadinata \& Nana Syaodih. (2005). Landasan Psikologi Proses Pendidikan. PT. Remaja Rosdakarya: Jakarta.

Suwangsih, Erna dan Tiurlina. (2006). Model Pembelajaran Matematika. UPI PRESS. Bandung.

Suyono \& Hariyanto. (2011). Belajar dan Pembelajaran. Bandung. PT Remaja Rosdakarya: Jakarta.

Usman, Moh. User. (1993). Upaya Optimalisasi Kegiatan Belajar Mengajar. Bandung: PT Remaja Rosdakarya. 